\title{
マクガーク効果における個人差
}

\begin{abstract}
重野純
要 約: マルチモーダルな音韻知覚に個人差が与える影響について, マクガーク効果の実験 を 3 週間の時間間隔をあけて 2 回行って調べた. 実験は 220 名の被験者に対して, 日常生活場 面の知覚条件に似た環境のもとで行い, 視聴覚情報が矛盾する刺激について, 視覚情報による 影響の程度と判断の一貫性について調べた. その結果, 被験者の判断分布は非常に広い範囲一 影響を強く受ける者から全く受けない者まで一にわたること，判断傾向は一貫していること， などの傾向が認められた. 実験結果から, マクガーク効果の実験の遂行や結果の解釈には, 個 人差などの被験者側の要因を考慮することが重要であることが示唆された。
\end{abstract}

索引用語: マクガーク効果, 個人差, 判断分布, 言語処理能力, 視聴覚情報

\section{Individual Differences Observed in McGurk Effect}

\section{Sumi Shigeno}

\begin{abstract}
The effects of individual differences on multimodal speech perception were investigated using the McGurk effect paradigm. Two successive experiments were conducted with an interval of three weeks. Two hundred and twenty subjects participated in the experiments, which were carried out under presentation conditions similar to daily-life andio-visual presentation. The experiments examined the amount of visual influence on perception of audio-visually incompatible syllables and consistency of judgments. Results showed that distribution of judgments of subjects is of very wide range - from subjects who are strongly influenced to those who are not at all-and tendencies of judgments are consistent. This suggests that factors of subjects such as individual differences are very important when conducting McGurk effect experiments and interpreting the results.
\end{abstract}

Key words : McGurk effect, individual differences, distribution of judgments, speech processing ability, audio-visual information

\section{はじめに}

日常生活において音韻の知覚は円滑なコミュニケー ション行動を行う上で, 非常に重要な役割を果たして いる.通常われわれは聴覚を通して音韻を知覚するが, 状況に応じて聴覚以外の種々の感覚情報を利用するこ
ともある、たとえば，相手のジェスチャーや唇の動き (構音運動)などを利用する．このような非音声情報を 利用して行う音韻知覚に生じる現象の一つに, マクガ ーク効果 (McGurk effect) がある.

McGurk and MacDonald（1976) ${ }^{1)}$ は，視覚情報と して唇を開いて発話する非唇音の/ga-ga/を提示し， 
聴覚情報として唇音の/ba-ba/を提示すると, 被験者 の多くは視覚情報でも聴覚情報でもない/da- da/とい う反応を示すことを見出した. McGurk らはこのよう な反応を融合反応 (fusion response) と呼んだ。また, 聴覚が非唇音/ga-ga/で視覚が唇音/ba-ba/の様な場 合には, 融合反応はほとんど生じないで，代わりに両 方の子音を含むような反応 (例, bga など)が生じるこ とを示し，それらを複合反応 (combination response) と呼んだ。このような現象が生じるのは，われわれの 音韻知覚が構音運動についての視覚情報を積極的に受 け入れており, 音韻情報処理のいずれかの過程で, 視 聴覚情報が何らかの形で統合されているためと考えら れる. McGurk らはマクガーク効果が生じる理由とし て, 視覚情報は構音についての場所情報を提供し, 聴 覚情報は構音様式に関する情報を提供して両者が統合 されるためであると考え,さらに視覚と聴覚の統合時 の情報はカテゴリ的で離散量であると考えた（MacDonald and McGurk, 1978) ${ }^{2)}$. しかし，このような考 え方は今日では，ほとんど䛊りであると考えられてい る (Summerfield, 1987) ${ }^{3)}$.

マクガーク効果は音韻情報処理過程を考える上で重 要な示唆を多数含んでいるので, その後もさまざまな 研究が行われてきた（重野，1993）年．そして日本人を 対象とした実験では, McGurk らが融合反応と呼んだ 反応が生起しやすい者とそうでない者に分かれる傾向 にあることが報告されている（重野，1996） ${ }^{5}$ ．心理実 験の多くは実験結果が正規分布などの一峰性の分布を なすと仮定し，個人差を誤差として扱うが，もし分布 が一様であったり二極化を示すとしたら，少数の被験 者を対象とする実験から一般的な結論を導くことは, 誤つた結論を下す危険を伴うといえよう。マクガーク 効果のようにある反応（例, 融合反応）が生じる者と 生じない者とに分かれやすい傾向にある結果について は, 個人差などの被験者側の要因を十分に検討してお くことが大切である. しかしマクガーク効果の生起に おける個人差を調べた実験は，これまでほとんど行わ れていない.

Watson, Qiu, Chamberlain, and Li (1996) ${ }^{6)}$ は, 90 名の聴覚正常な大学生に対して, 単語と文章につい て, 聴覚からの音声言語の聞き取り能力と読唇（lipreading) 能力との関係に個人差が認められるかどうか を調べた。その結果, 聞き取りの成績と読唇の成績の 間の相関係数 $(r)$ は 0.43 から 0.52 の間にあり, 読 唇能力の高い者は聞き取り能力も高いことが示され た.この結果は, 感覚の種類には依存しない言語処理 能力に, 優劣の差があることを示すものと考えられた。
さらに，被験者が女性の場合には男性の場合よりも， 読唇において有意に良い成績が得られた。

Watson らの研究は, 視聴覚情報処理の能力に個人 差があることを示すものだが, 視覚と聴覚の検査をそ れぞれべつべつに行ったものであり, 視聴覚刺激に対 する処理能力すなわち bimodal な処理が必要とされ るときに, 視覚と聴覚の情報のどちらを優位に処理に 用いるかについての個人差を示したものではない.一 般的には，視覚的補獲（visual capture）の例にみられ るように，音源定位などにおいて視覚優位が認められ ている（たとえば, 腹話術（師）効果（ventriloquism effect）など).

本研究の目的は, マクガーク効果の生起に個人差が 認められるのかどうか, またその大きさはどれくらい であるのかについて調べることである.さらにマクガ ーク効果の生起は頑健 (robust) であると一般にいわれ るが, どの程度一貫して生じるものであるかについて も検討する.実験室内での厳密な統制条件のもとでは, 知覚能力の他に実験場面における個人の適応性が関わ ってくると考えられるので, 本研究ではより日常生活 場面での知覚条件に似ていると考えられる大教室内で のスクリーンとスピーカによる提示方法のもとで実験 を行うこととした。ささらに, 個人差をより適切に得る ために，デー夕を集める被験者の数は数百人単位の多 数になるようにした。

\section{方 法}

被験者：日本人の大学 1 年生 220 名（男 48 名, 女 172 名）が，授業の一部として実験に参加した。

刺激：刺激は 9 通りの視聴覚刺激であった. 表 1 は 刺激の一覧とその表記方法を表している. 刺激の作成 には, 日本人女性 1 名を発話者として用い, 発話場面

表 1 実験に用いた視聴覚刺激

\begin{tabular}{ccc}
\hline 聴覚情報 & 視覚情報 & 表記 \\
\hline \multirow{3}{*}{ ba } & $\mathrm{ba}$ & $\mathrm{AbVb}$ \\
& $\mathrm{da}$ & $\mathrm{AbVd}$ \\
& $\mathrm{ga}$ & $\mathrm{AbVg}$ \\
\hline \multirow{3}{*}{$\mathrm{da}$} & $\mathrm{ba}$ & $\mathrm{AdVb}$ \\
& $\mathrm{da}$ & $\mathrm{AdVd}$ \\
& $\mathrm{ga}$ & $\mathrm{AdVg}$ \\
\hline \multirow{3}{*}{$\mathrm{ga}$} & $\mathrm{ba}$ & $\mathrm{AgVb}$ \\
& $\mathrm{da}$ & $\mathrm{AgVd}$ \\
& $\mathrm{ga}$ & $\mathrm{AgVg}$ \\
\hline
\end{tabular}


の録画と音声の収録をべつべつに行った。発話者には, 「明瞭にしゃべるよう」に指示した。まず/ba/, / da/, $/ \mathrm{ga} /$ の各音節を 3 回ずつ発話し, 8 ミリビデオカメラ (SONY, ACP-80) を用いて, ビデオテープのアフレ コ用音声トラックに PCM 方式で録音した. 次に, 話者 の首から上を同上の 8 ミリビデオで撮影した。音声刺 激,映像刺激はともに編集のために,それぞれ別の $1 / 2$ インチ S-VHS テープにダビングした後, 音声刺激に ついては 9 名の被験者（上述の被験者とは異なる）に 対して音声の聞き取りテストを行い，各音節について 最も明瞭度のすぐれた 1 個を選んだ。

次に, 最も明瞭な刺激として選ばれた音声刺激を映 像刺激に同期させた。同期の精度は映像フレーム単位 （33.3 ms）とした。 2 名の聴取者が最も自然に感じら れるまで同期を繰り返し，実験に用いる 9 通りの組み 合わせを選んだ。各音節の持続時間は 370〜 400 ms で あった。

映像と音声の 9 通りの組み合わせをランダムに 10 回ずつ別の S-VHS テープにダビングし，その前後に 2 試行ずつのダミーを加えて合計 94 試行からなる刺 激系列を作成した。映像刺激は 6 秒ごとに提示した。 映像は音声の立ち上がり時点の $0.9 \mathrm{~s}$ 前から提示し た。映像の提示時間は $1.8 \mathrm{~s}$ とした。映像間は $4.2 \mathrm{~s}$ の 白地とし,この時間内に反応を記入するよう指示した。

手続き：実験は約 300 名を収容できる大教室におい て行った。刺激はビデオデッキ（SONY，VPH 2042 QJ）で再生し, 映像はスクリーン（縦 $3 \mathrm{~m} \times$ 横 $3 \mathrm{~m}$ ) に提示し, 音声はスクリーンの両側にあるスピーカ （Victor, SMBM-330）から提示した．被験者の観察距 離は，着席位置によって約 $3 \mathrm{~m}$ から約 $15 \mathrm{~m}$ にわたっ た。音声の音圧レベルは各音節とも，66 dB(A）（最後 列右端の席）から $75 \mathrm{~dB}$ （A）（最前列中央の席）の範 囲であった。

実験は，音声と映像を同時に提示し，被験者は反応 の記入以外は常にスクリーンから目を離さないよう厳 重に指示された，被験者は映像をみながら音声を受聴 し，「何といっているように聞こえたか」を判断するよ う求められた。この際, 話者の唇を注視してその動き をよくみるように指示した，実験者が教室の中を巡回 し，指示の徹底をはかった。 反応はローマ字で，ba， da, ga のように記入し，日本語にない場合にも，たと えばbgaのように聞こえたままに正確に記入するよ うに求めた。

実験は 1995 年 11 月 21 日に第 1 回目を行い, 3 週間 後の同年 12 月 12 日に第 2 回目を行った. 1 回目の実 験の前に若干の練習を行った。2 回の実験とも，9種
類の視聴覚刺激について，それぞれ被験者一人当たり 10 回の反応を得た. 2 回の実験の際の着席位置は自由 としたが，ほとんどの被験者が 2 回ともほぼ同じ位置 に着席した。

データの処理方法：3 週間の時間間隔を経たことに よって, マクガーク効果の生起率がどれくらい変化し たかをみるために, 1 回目と 2 回目の判断を比較する. そのために，各刺激の聴覚成分への同定率について， 1 回目と 2 回目の間の相関係数を求める.さらに，マ クガーク効果に生じる個人差をみるため, 融合反応数 と複合反応数で分類した被験者数の分布をそれぞれ示 し，その分布が一様分布なのかそれとも特定の分布を 示すのかについて検定を行って調べる.

\section{結果}

\section{1 回目と 2 回目の結果の比較}

表 2 は 9 種類の視聴覚刺激について, どのような反 応が得られたかを示す一覽表である。上段が 1 回目, 下段が 2 回目の反応カテゴリと反応率（聴覚成分への 同定率）を示し，それぞれ全被験者の平均を表してい る. 表 2 より，1 回目と 2 回目の反応にはカテゴリご との反応率にほとんど差のないことが認められる。 た, 表 2 の右端の欄には聴覚情報への反応率の 1 回目 と 2 回目の間の相関係数を刺激ごとに載せてある．相 関係数は 0.53 から 0.78 の範囲にあり, 高い正の相関 が認められた。図 1 は, AbVd と AbVg に対する/da/ の反応の頻度分布を 1 回目と 2 回目の相関図として描 いたものである，正の相関関係にあることが明瞭に認 められる。つまり，若干の例外はあるが，大多数の被 験者の判断傾向は 3 週間にわたる時間間隔があいても 大きな変化を示さないことが認められた。なお，着席 位置による影響は認められなかった。

次に，いわゆる融合反応や複合反応と呼ばれる反応 が，どれくらい一貫して認められるのかを調べるため に, $\mathrm{AbVd}, \mathrm{AbVg}$ の場合の/da/の反応数と AdVb, $\mathrm{AgVb}$ の場合の複合反応数を 1 回目と 2 回目の間で比 較した。前者については視覚条件が $/ \mathrm{da} /$ の時も/ga/の 時も反応傾向がよく似ているので，ここでは $\mathrm{AbVd}$ と $\mathrm{AbVg}$ の場合の/da/の反応数を合計した. 1 回目と 2 回目の間で比較すると,相関係数は 0.76 であり高い正 の相関が得られた。同様に，聴覚条件が/da/の時も $/ \mathrm{ga} /$ の時も反応傾向がよく似ているので, AdVb と $\mathrm{AgVb}$ の場合の複合反応数を合計して 1 回目と 2 回目 の間で比較した。相関係数は 0.78 であり,やはり高い 正の相関関係にあることが認められた。 
表 2 各視聴覚刺激に対する反応カテゴリとそれへの反応率, および聴覚情報と同じカテゴリへ同定した反応数の 1 回目と 2 回目の間の相関係数

\begin{tabular}{|c|c|c|c|c|c|c|}
\hline \multicolumn{2}{|c|}{ 刺激 } & \multicolumn{4}{|c|}{ 反応 } & \multirow{2}{*}{$\frac{\text { 相関係数 }}{(\mathrm{r})}$} \\
\hline 聴賞 & 視覚 & ba & da & ga & others & \\
\hline \multirow{6}{*}{$\mathrm{ba}$} & \multirow[t]{2}{*}{ ba } & 88.8 & 0.5 & 0.1 & $10.6(7.1)$ & \multirow{2}{*}{0.67} \\
\hline & & 87.4 & 0.7 & 0.3 & $11.5(8.1)$ & \\
\hline & $\mathrm{da}$ & 26.0 & 53.0 & 2.6 & $18.4(11.0)$ & \multirow{2}{*}{0.77} \\
\hline & & 28.2 & 52.0 & 2.0 & $17.9(11.9)$ & \\
\hline & \multirow[t]{2}{*}{ ga } & 21.4 & 44.2 & 5.6 & 28.2 (13.5) & \multirow{2}{*}{0.73} \\
\hline & & 23.7 & 48.3 & 4.0 & $24.0(11.5)$ & \\
\hline \multirow{6}{*}{ da } & \multirow[t]{2}{*}{ ba } & 19.2 & 41.1 & 1.8 & $37.9(34.0)$ & \multirow{2}{*}{0.78} \\
\hline & & 13.8 & 42.5 & 2.0 & $41.6(42.6)$ & \\
\hline & da & 0.7 & 88.9 & 5.1 & $5.4(3.5)$ & \multirow{2}{*}{0.67} \\
\hline & & 0.5 & 92.3 & 3.0 & $4.1(3.1)$ & \\
\hline & \multirow[t]{2}{*}{ ga } & 0.4 & 79.5 & 9.6 & $10.4(3.7)$ & \multirow{2}{*}{0.65} \\
\hline & & 0.5 & 86.0 & 4.7 & $8.9(4.1)$ & \\
\hline \multirow{6}{*}{$\mathrm{ga}$} & \multirow[t]{2}{*}{ ba } & 5.2 & 0.3 & 48.8 & $45.7(42.6)$ & \multirow{2}{*}{0.71} \\
\hline & & 3.2 & 0.4 & 43.6 & $52.9 \quad(52.2)$ & \\
\hline & da & 0.1 & 1.9 & 88.9 & $9.1(7.0)$ & \multirow{2}{*}{0.63} \\
\hline & & 0.3 & 1.0 & 86.5 & $12.3(10.7)$ & \\
\hline & \multirow[t]{2}{*}{ ga } & 0.0 & 0.8 & 93.9 & $5.3(2.6)$ & \multirow{2}{*}{0.53} \\
\hline & & 0.0 & 1.1 & 94.0 & $4.9(2.6)$ & \\
\hline
\end{tabular}

上段は 1 回目, 下段は 2 回目の結果.（）中の教字は, 複合反応 の\%を表す

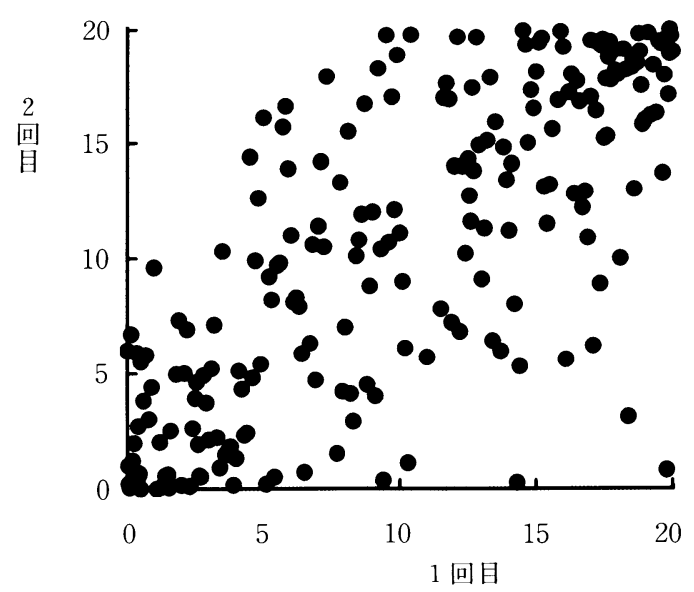

図 11 回目と 2 回目に $\mathrm{AbVd}$ と $\mathrm{AbVg}$ に対して “da”と反応した反応数の相関図

\section{2. 反応カテゴリと反応率}

表 2 より，聴覚情報と同じカテゴリへ同定した割合 (表中の網掛け部分) は視聴覚情報が一致している場合 の方が一致していない場合よりも高い傾向にあること が認められる。しかし視覚情報が聴覚情報と矛盾して いる場合，特に聴覚情報が唇音の/ba/で視覚情報が非 唇音の/da/ないし/ga/の場合 $(\mathrm{AbVd}, \mathrm{AbVg})$ には, $/ \mathrm{da} /$ への同定率の低下が大きい.この場合, $/ \mathrm{da} /$ へ反 応しやすいことが認められる。ここで, $\mathrm{AbVb}$ と $\mathrm{AbVd}, \mathrm{g}$ 間で “da” と“da 以外”のカテゴリへの同定 度数について $\chi^{2}$ 検定を行ったところ， $\chi^{2}=3103.53$ ， $d f=1, \mathrm{~N}=13200, p<.005$ で, $\mathrm{AbVd}, \mathrm{g}$ の刺激に対 して有意に/da/への同定が増大していることが認め られた。一方, 聴覚情報が非唇音の/da/ないし/ga/で 視覚情報が唇音の/ba/の場合 $(\mathrm{AdVb}, \mathrm{AgVb})$ にも聴 覚情報への同定率は低下するが，この場合には/da/で はなく/bga/のような二つ以上の子音が結合している 複合反応の生起しやすいことが認められた $(\mathrm{AdVd}$, 
$\mathrm{AgVg}$ と $\mathrm{Ad}, \mathrm{gVb}$ 間で “複合反応” と “複合反応以外” のカテゴリへの同定度数について比較したところ, $\chi^{2}=3814.38, d f=1, \mathrm{~N}=17600, p<.005$ で, Ad, $\mathrm{gVb}$ の刺激に対して有意に複合反応が増大している ことが示された)。

実験室内の統制された条件下で生じる日本人のマク ガーク効果についてはこれまでにもいろいろと報告さ れている.今回の実験結果を一人ずつ実験室内で行っ

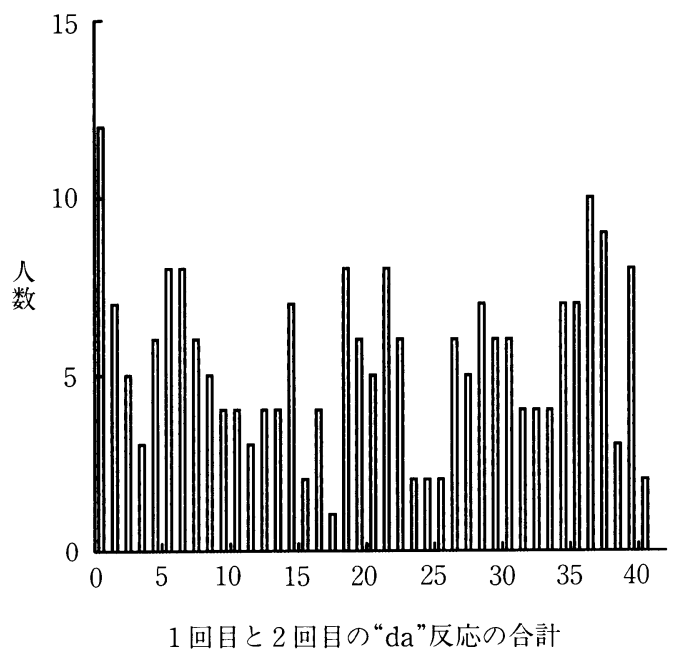

図 $2 \mathrm{AbVd}$ と AbVgに対して“da”と判断した反 応数の分布. 1 回目と 2 回目の結果を合計し たもの

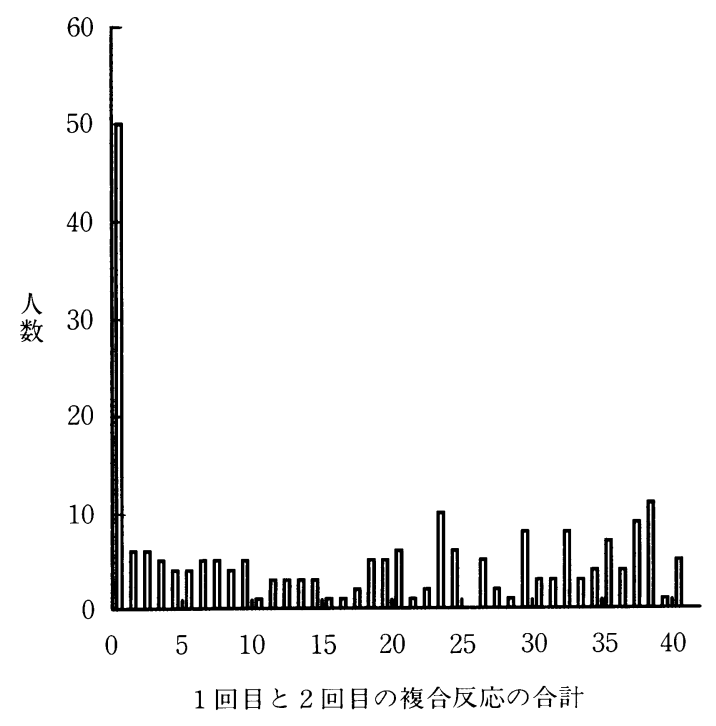

図 $3 \mathrm{AdVb}$ と $\mathrm{AgVb}$ に対する複合反応数の分布. 1 回目と 2 回目の結果を合計したもの
た場合の結果と比較すると，たとえば $\mathrm{AbVg}$ に対す る/da/への同定率は, 重野 (1993) では $56.2 \%$ (被験 者 24 名の平均) であったが，本実験結果では $44.2 \%$ (1 回目) と $48.3 \%$ （2 回目）であり, 今回の方が低 い傾向にある。このように実験室内での結果に比べれ ば減少傾向にあるものの, 本実験の結果から, 映画や テレビをみるといった日常生活場面に近い状況の実験 においても, マクガーク効果の生じることが明らかと なった。

\section{3. 視聴覚刺激の知覚における個人差}

図 2 は, $\mathrm{AbVd}, \mathrm{AbVg}$ に対する/da/への反応数の分 布を表している. 1 回目と 2 回目の相関が高いことが 分かっているので, 2 回分のデー夕は合計してある. コルモゴロフ・スミルノフの検定を用いて一様分布へ の適合性の検定を行うと, $\mathrm{D}=0.05, \mathrm{~N}=220, p>0.2$ となり, /da/への反応数の分布は, 統計的に一様分布 とみなしうることが明らかとなった。つまり融合反応 を示す者から全く示さない者までほぼ一様に分布する ことが示された。

図 3 は, $\mathrm{AdVb}, \mathrm{AgVb}$ に対する複合反応数の分布を 示している。図 2 とは異なり複合反応が全く生じない ものが全被験者のほぼ $1 / 4$ にのぼる.コルモゴロフ・ スミルノフの検定を行うと, $\mathrm{D}=0.2, \mathrm{~N}=220, p \dot{<} 0.01$ となり, 複合反応数の分布に偏りが有意に生じること が認められた。また複合反応を示さない被験者を除い てコルモゴロフ・スミルノフの検定を行うと, $\mathrm{D}=$ $0.088, \mathrm{~N}=170, p>0.10$ となり, 複合反応を示す者の 分布が一様なことが示された. したがって, 複合反応 については, 全く生じない者が多数いるだけではなく, 生じる被験者の場合, その分布は一様であることが分 かった.

\section{考察}

マクガーク効果の生起が頑健であることはこれまで の研究においても報告されている。たとえば，CVCの 無意味語の知覚において, 視覚と聴覚の情報の提示が 時間的にずれている場合にも, マクガーク効果の生じ ることが報告されている (Smeele, Sittig, and van Heuven, 1992) ${ }^{7}$. さらに, 映像中の人物と音声刺激の 人物が性の異なる（たとえば，女性の顔の映像をみせ ながら男性の声を聞かせる）場合にも，マクガーク効 果の生じることが報告されている (Green, Kuhl, Meltzoff, and Stevens, 1991) ${ }^{8)}$.また, 聴覚情報がノイズ によって聞き取りにくい場合にマクガーク効果が顕著 になるという報告 (Dodd, 1977) $\left.{ }^{9}\right)$ から，一般に聴覚だ けでは判断が困難な場合に, 視覚情報が利用されると 
考えられている.

本実験の結果は, 実験室内での実験ばかりでなく, 大教室内の集団実験のように，テレビや映画をみると いった日常生活場面に近い刺激提示条件の場合にも, マクガーク効果が生じることを示している．したがっ てマクガーク効果の生起は従来いわれているように非 常に頑健であり, また 2 回の実験間の相関も高かった ことから再現性もあることが認められた。その一方で 視覚情報を音韻知覚のための情報処理に全く取り入れ ない被験者が少なからず存在することを示した．本実 験の範囲では, その理由については不明であるが, Watson らの報告においては感覚様相によらない言語 情報処理能力に個人差のあることが示されており, bimodal な情報の統合能力においても，個人差のある ことを原因の一つとして考えることができるだろう.

ところで, マクガーク効果は欧米人に比べ日本人に は生じにくいあるいは生じる量が少ないという報告が ある (Sekiyama and Tohkura, 1991) ${ }^{10)}$. しかし, 本 実験の結果では, 視覚情報と聴覚情報の組み合わせに よっては，ほとんど生じない者から顕著に生じる者ま で存在しており，特に複合反応に関しては全く生じな い者が全被験者の四分の一に認められる一方で, 生じ る被験者についてもその量の大小からみると, ほほ一 様の分布にある傾向が示された．欧米人の場合には非 常に顕著にマクガーク効果が生じる(例, McGurk and MacDonald, 1976) ことから, 被験者の反応分布が日 本人の場合とは異なることも可能性の一つとして推測 される.より多数の被験者を用いて欧米人に対しても 個人差を検討することが必要であろう。

マクガーク効果はマルチモーダルな情報処理の観点 からみて非常に興味深い現象である.しかし, 研究間 で矛盾した結果を示す場合もある。たとえば, CV 音節 中の後続母音により, マクガーク効果の大きさが影響 を受けるかどうかについては後続母音の種類によって マクガーク効果の大きさが異なるという報告（Green, Kuhl, and Meltzoff, 1988 ${ }^{11)}$; Green and Gerdeman, $1995^{12)}$;重野，1993 ${ }^{13)}$ ) がある一方，母音による影響は ないとする報告 (Massaro, Cohen, and Gesi, 1993) ${ }^{14)}$ もある。このような矛盾した実験結果の生じる原因に ついてはさらに検討を要するが, 個人差などの被験者 側の要因も原因の一つとして考えられる．以上の点か ら, マクガーク効果の実験を行う際には個人差のある ことを考慮に入れて，かなり大きな被験者グループを 用いた実験条件の設定を行い, 結果の解釈には個人差 など被験者側の要因に対して十分な注意を払うことが 必要であるといえよう。

\section{おわりに}

本実験の結果より, 構音運動を表す視覚情報が音韻 知覚に及ぼす影響には個人差が認められた。そのため, $\mathrm{AbVd}, \mathrm{g}$ に対する/da/への反応数で分類した被験者 数の分布は一峰性の分布を示さず，視覚情報の影響を 著しく受けやすい者から全く受けない者まで一様に分 布することが認められた。また，Ad, gVbに対する複 合反応においても同様に一峰性の分布は示さないが, 生じる者と全く生じない者に分かれ，生じる者の場合 その量の大小に関しては分布が一様であることが認め られた。さらに，このような反応傾向は 3 週間という 時間間隔をおいてもほとんど変わらず，再現性のある ことが示された。また，視聴覚間で情報が矛盾してい る刺激に対して判断を下すことは非常に不自然な行動 であるが, 従来の研究のように実験室内での厳格な統 制条件下でないより日常生活に近い知覚場面において も生じることが認められ, 従来いわれているようにマ クガーク効果の生起は非常に頑健であることが認めら れた。これらの結果から，マクガーク効果の生起には 個人差などの被験者側の要因が及ぼす影響の大きいこ とが示唆された。

\section{文献}

1) McGurk, H., MacDonald, J. : Hearing lips and seeing voices. Nature, 264 : 746-748, 1976.

2) McDonald, J., McGurk, H. : Visual influences on speech perception processes. Perception \& Psychophysics, 24 : 253-257, 1978.

3) Summerfield, Q. : Some preliminaries to a comprehensive account of audio-visual speech perception. Hearing by eye : The psychology of lip -reading (edited by Dodd, B. and Campbell, R. ), Lawrence Erlbaum Associates, Hillsdale, NJ, pp. 3-51, 1987.

4）重野 純：音声言語の知覚における視聴覚情報の 統合過程. 知覚の機序 (鳥居修晃・立花政夫編), 培風館, 東京, 90-109 頁, 1993.

5）重野 純：McGurk 効果における個人差につい て. 日本音響学会秋季講演論文集 : 347-348, 1996.

6) Watson, C. S., Qui, W. W., Chamberlain, M. M., et al. : Auditory and visual speech perception : Confirmation of a modality-independent source of individual differences in speech recognition. Journal of the Acoustical Society of America, $100: 1153-1162,1996$. 
7) Smeele, P. M. T., Sittig, A C., van Heuven, V. J. : Intelligibility of audio-visually desynchronized speech : Asymmetrical effect of phoneme position. Proceedings of $2^{\text {nd }}$ ICSLP, pp. 65-68, 1992.

8) Green, K. P., Kuhl, P. K., Meltzoff, A. N., et al. : Integrating speech information across talkers, gender, and sensory modality : Female faces and male voices in the McGurk effect. Perception \& Psychophysics, 50 : 524-536, 1991.

9) Dodd, B. : The role of vision in the perception of speech. Perception, $6: 31-40,1977$.

10) Sekiyama, K., Tohkura, Y. : McGurk effect in non-English listeners : Few visual effects for Japanese subjects hearing Japanese syllables of high auditory intelligiblity. Journal of the Acoustical Society of America, 90 : 1797-1805, 1991.

11) Green, K. P., Kuhl, P. K., Meltzoff, A. N. : Factors affecting the integration of auditory and visual information in speech : The effect of vowel environment. Journal of the Acoustical Society of America, 84 : S155, 1988.

12) Green, K. P., Gerdeman, A. : Cross-modal discrepancies in coarticulation and the integration of speech information: The McGurk effect with mismatched vowels. Journal of Experimental Psychology : Human Perception and Performance, $21:$ 1409-1426, 1995.

13）重野 純：視聴覚情報の統合に及ぼす刺激文脈の 影響。日本音響学会秋季講演論文集 : 385-386, 1993.

14) Massaro, D. W., Cohen, M. M., Gesi, A. T. : Long-term training, transfer, and retention in learning to lipread. Perception \& Psychophysics, $53:$ 549-562, 1993

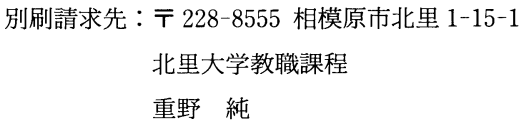

